\title{
Interfamilial Amplexus between a Male Polypedates leucomystax (Gravenhorst 1829) (Anura: Rhacophoridae) and a Female Leptobrachium hendricksoni Taylor 1962 (Anura: Megophryidae) from Peninsular Malaysia
}

\author{
Shahriza Shahrudin
}

School of Pharmaceutical Sciences, Universiti Sains Malaysia, 11800 Penang, Malaysia (shahriza20@yahoo.com)

$T^{3}$ he Four-lined Treefrog (Polypedates leucomystax), a moderately large rhacophorid (SVL 50-80 mm) often bearing four longitudinal dorsal stripes (Berry 1975), is frequently associated with humans throughout a broad range that spans Bangladesh, Brunei, Cambodia, China, India, Indonesia, Laos, Malaysia, Myanmar, Nepal, the Philippines, Singapore, Thailand, and Vietnam (Diesmos et al. 2004). In mainland peninsular Malaysia, it occupies various habitats, appears to be most abundant around human habitations in both urban and rural areas (Berry 1975; Ibrahim et al. 2008; Diesmos et al. 2004), but also can be found in lowlands and disturbed forests (Ibrahim et al. 2008; Grismer 2011). The Spotted Litterfrog (Leptobrachium hendricksoni) is a medium-sized megophryid (SVL 46-63 mm) with small to large black dots on the venter (Berry 1975). This slow-moving frog is known from Thailand, Malaysia, and Indonesia, generally at elevations below 1,000 m asl (IUCN SSC Amphibian Specialist Group 2014). In Peninsular Malaysia, it inhabits forest-floor litter near stream banks and flat swampy areas of primary and secondary forests (Berry 1975; Ibrahim et al. 2008).

Between 2100 and $2200 \mathrm{~h}$ on 14 February 2015, I observed amplexus (Fig. 1) involving a male P. leucomystax (SVL $47 \mathrm{~mm}$, mass $8 \mathrm{~g}$ ) and a female L. hendricksoni (SVL $60 \mathrm{~mm}$, mass $15 \mathrm{~g}$ ) in the Sungai Sedim Recreational Forest, Kedah, Malaysia $\left(5^{\circ} 25^{\prime} \mathrm{N}, 100^{\circ} 46^{\prime} \mathrm{E}\right.$; elev. $<150 \mathrm{~m}$ asl). The pair was on forest floor leaf litter, 2-3 $\mathrm{m}$ from a rocky pool (1 x $0.5 \mathrm{~m}$, depth $3-18 \mathrm{~cm}$ ) situated between two granite rocks and sheltered by lowland dipterocarp forest. Air temperature and relative humidity were $23{ }^{\circ} \mathrm{C}$ and $74 \%$, respectively. The eyes of both frogs were partially open and sometimes closed. The amplected pair was immobile for approximately $10 \mathrm{~min}$ before slowly moving toward the nearby pool, stopping at least three times along the way. I encountered two other frog species, the Indian Cricket Frog (Fejervarya limnocharis) and Black-sided Narrow-mouthed Frog (Microhyla heymonsi), near and in the pool. I captured the amplected pair, brought them to the laboratory, measured snout-vent length and mass using a digital calliper and electronic balance, and euthanized and fixed them with $10 \%$ formalin. Specimens were stored in 70\% ethanol and deposited at the School of Pharmacy, Universiti Sains Malaysia (15USM-SS-PL01 and 15USMSS-LH01).

Recent published reports of heterospecific amplexus include Machado and Bernarde (2011), Sodre et al. (2014),

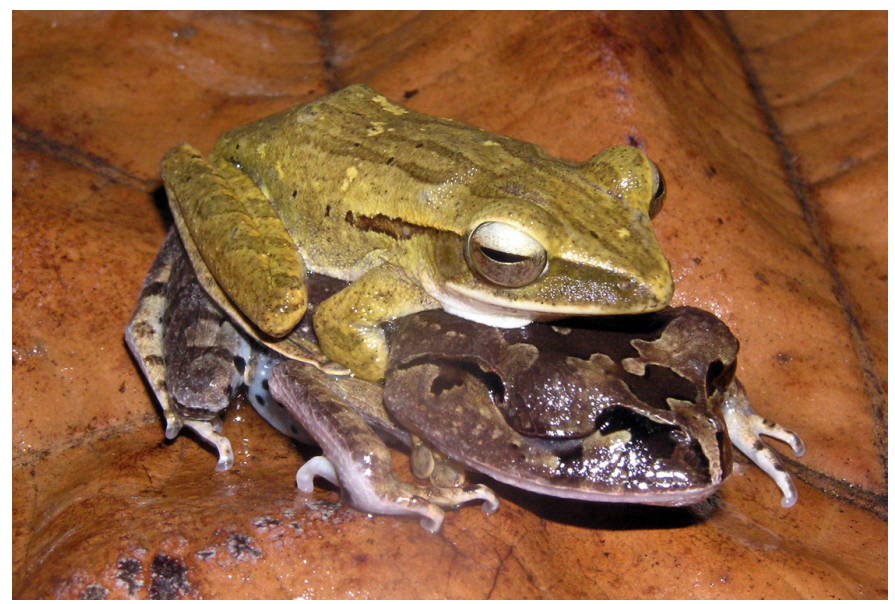

Fig. 1. Heterospecific amplexus involving a male Four-lined Treefrog (Polypedates leucomystax) and a female Spotted Litterfrog (Leptobrachium hendricksoni) in the Sungai Sedim Recreational Forest, Kedah, Malaysia. Photograph by the author. 
Rocha et al. (2015), Bhattarai et al. (2018), and Gul et al. (2018). In peninsular Malaysia, Shahriza (2016) recorded heterospecific amplexus between a male Jade Treefrog (Rhacophorus prominanus) and a female Polypedates leucomystax. Efforts to explain the occurrence of heterospecific amplexus include overlap in reproductive activities (Hobel 2005), a disproportionately smaller number of females (Wogel et al. 2005), a high number of competing males (Wells 2007), noisy environments (Wells 2007), confusion of chemical signals (Mollov et al. 2010), low selectivity toward females (Machado and Bernarde 2011), long-term absence of conspecific females (Vivek et al. 2014), and explosive breeding (Machado and Bernarde 2011; Vivek et al. 2014). I cannot say with any certainty which, if any, apply in this situation.

\section{Acknowledgements}

I express my gratitude to the Universiti Sains Malaysia, Penang for the facilities and amenities provided. This research project was funded by Universiti Sains Malaysia, Research University Grant (1001/PFARMASI/8011004).

\section{Literature Cited}

Berry, P.Y. 1975. The Amphibian Fauna of Peninsular Malaysia. Tropical Press, Kuala Lumpur, Malyasia.

Bhattarai, S., P. Gotame, C.P. Pokheral, B.R. Lamichhane, R.C. Kandel, and N. Subedi. 2018. Interspecific amplexus of a Six-lined Treefrog, Polypedates taeniatus (Boulenger, 1908), and a Chunam Treefrog, P. maculatus (Gray, 1830) (Anura: Rhacophoridae), in Chitwan National Park, Nepal. Reptiles \& Amphibians 25: 29-30.
Diesmos, A.C., A. Alcala, R. Brown, L.E. Afuang, G. Gee, J. Sukumaran, N. Yaakob, L. Ming, Y. Chuaynkern, K. Thirakhupt, I. Das, D. Iskandar, Mumpuni, R.F. Inger, R. Stuebing, P. Yambun, and M. Lakim. 2004 (errata version published in 2016). Polypedates leucomystax. The IUCN Red List of Threatened Species 2004: e.T58953A86477485 (http://www.iucnredlist.org/ details/58953/0).

Grismer, L.L. 2011. Amphibians and Reptiles of the Seribuat Archipelago. Edition Chimaira, Frankfurt, Germany.

Gul, S., N. Ozdemir, and C. Dursun. 2018. First record of interspecific amplexus behaviour between Bufotes variabilis (Pallas, 1769) and Pelophylax ridibundus (Pallas, 1771) with Bufo bufo (Linnaeus, 1758) (Anura: Bufonidae) from Turkey. Herpetology Notes 11: 153-155.

Ibrahim, H.J., M.S. Shahrul Anuar, A. Norhayati, K.O. Chan, and M.A. Mohd Abdul Muin. 2008. The Common Amphibians and Reptiles of Penang Island. The State Forestry Department of Penang, Georgetown, Malaysia.

IUCN SSC Amphibian Specialist Group. 2014. Leptobrachium hendricksoni. The IUCN Red List of Threatened Species 2004: e.T57555A63112900 (http:// www.iucnredlist.org/details/57555/0).

Machado, R.A. and P.S. Bernarde. 2011. Multiple and heterospecific amplexi between the toads Rhaebo guttatus and Rhinella marina (Anura: Bufonidae). Herpetology Notes 4: 167-169.

Mollov, I.A. 2010. Cases of abnormal amplexus in anurans (Amphibia: Anura) from Bulgaria and Greece. Biharean Biologist 4: 121-125.

Rocha, S.M., D.O. Santana, I.R.S. Silva, and R.G. Faria. 2015. Interspecific amplexus between Hypsiboas albomarginatus (Spix, 1824) and Hypsiboas raniceps Cope, 1862 (Anura: Hylidae) in northeastern Brazil. Herpetology Notes 8: 213-215.

Shahrudin, S. 2016. Interspecific amplexus between male Rhacophorus prominanus and female Polypedates leucomystax from peninsular Malaysia. The Herpetological Bulletin 135: 30-31.

Sodre, D., A.A.V. Martins, and M. Vallinoto. 2014. Heterospecific amplexus between the frog Leptodactylus macrosternum (Anura: Leptodactylidae) and the toad Rhinella cf. granulosa (Anura: Bufonidae). Herpetology Notes 7: 287-288.

Theis, T.F. and V.M. Caldart. 2015. Multiple interspecific amplexus between a male of the invasive Bullfrog Lithobates catesbeianus (Ranidae) and two males of the Cururu Toad Rhinella icterica (Bufonidae). Herpetology Notes 8: 449-451. 